\title{
Prediction of Rainfall Intensity as Early Warning Information on Potential Landslides using Fuzzy Logic (Case Study Weste " :" Lampung Regency)
}

\author{
Daniel Rinaldi ${ }^{1}$, Rahman Indra Kesuma ${ }^{2}$, M. Yafi Fahmi ${ }^{3}$, Winda Yulita ${ }^{4} *$, Mugi \\ Praseptiawan $^{5}$, Aidil Afriansyah ${ }^{6}$
}

\section{1,2,3,4,5,6 Informatics Engineering Study Program, Institut Teknologi Sumatera}

*Coresponding author: winda.yulita@if.itera.ac.id

\begin{abstract}
Landslides always happened in West Lampung Regency yearly, which makes early warning information of landslides is needed. There are many factors which can cause landslide, one of the important factors is rainfall intensity, which can be predicted. The prediction of rainfall intensity can be obtained by using fuzzy logic. The fuzzy logic used in this research is Mamdani, and this research show the similar result for most data which means that fuzzy logic might not be suitable to be used to forecast the rainfall if the obtained data has lots of missing values.
\end{abstract}

Keywords: Rainfall intensity prediction, Fuzzy Logic Mamdani

\section{Introduction}

Landslides is one of natural disasters which occurred when a movement of a mass of rock, soil or debris material that makes the slope moving down or out due to the influence of gravity [1]. Landslides also occurred in Indonesia, and it happened from year to year, which not only causing damage to nature and property, but it also can take lives [2].

Landslides can occur due to two factors, namely natural factors and human factors. Natural factors can be caused by rainfall, slopes, and soil conditions, while human factors are caused by human activities in land use that do not pay attention to the limitations of the physical conditions of the area, [3] especially in areas prone to landslides, earthquakes, and high rainfall intensity [4]. Tectonic conditions in Indonesia that form high morphology, faults, and volcanic rocks that are easily brittle and supported by a wet tropical climate, cause the potential for landslides to be high [2]. One of the impacts of landslides is the destruction of land use, so that community activities will be disrupted and cause losses not only material, but also non-material, such as death. Landslides that can take lives usually occur suddenly so that people who are hit by landslides do not have time to escape [3].

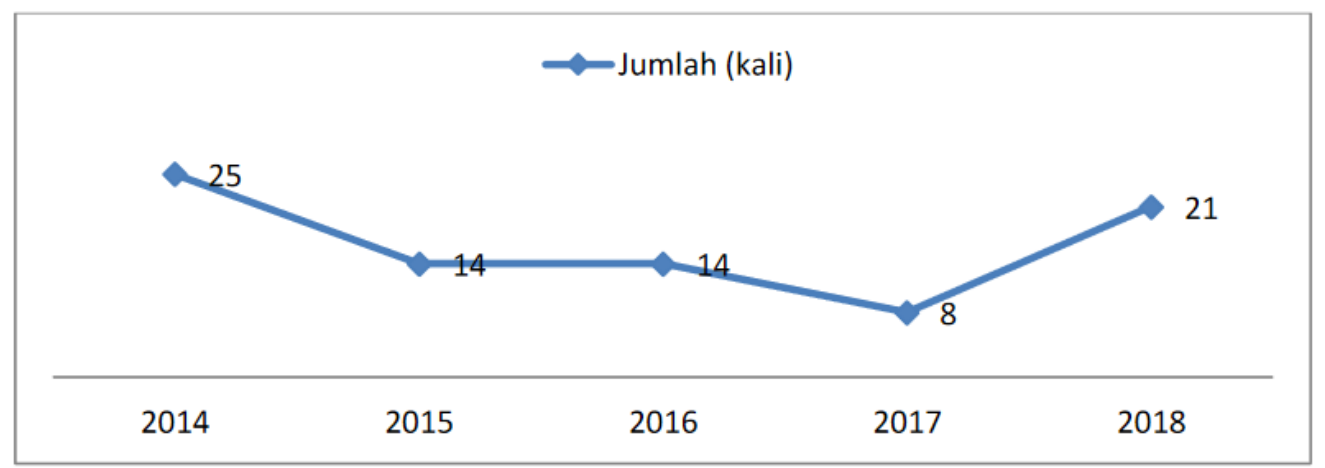

Figure 1. Landslide Incident in Lampung Province Year 2014-2018 [4] 
Lampung Province, one of the provinces in Indonesia landslides, based on the Lampung Province BPBD, the occuirence of landslidess from 2014 to 2018 as seen in Figure 1. Landslide Incident in Lanoping Provinece Year 2014-2018 Figure 1. [4] The distribution of landslides in Lampung Province from 2014 to 2017 as shown in Table 1. Landslide Disaster Data Per Regency in Lampung Province 2014-2017Table 1, shows that one of the districts that most frequently experienced landslides in Lampung Province was West Lampung, which was 13 times [5]. West Lampung District based on regional conditions and geomorphological conditions, is an area that is quite vulnerable to various types of natural disasters, such as earthquakes, landslides, and strong erosion [6].

Table 1. Landslide Disaster Data Per Regency in Lampung Province 2014-2017

[4]

\begin{tabular}{|c|c|c|c|c|c|}
\hline \multirow{2}{*}{ No. } & \multirow{2}{*}{ NAMA KABUPATEN } & \multicolumn{4}{|c|}{ TAHUN } \\
\hline & & 2014 & 2015 & 2016 & 2017 \\
\hline 1. & Bandar Lampung & 1 & 6 & 2 & - \\
\hline 2. & Metro & - & - & - & - \\
\hline 3. & Lampung Tengah & - & - & - & - \\
\hline 4. & Lampung Selatan & 2 & - & 1 & 1 \\
\hline 5. & Tulang Bawang Barat & - & - & - & - \\
\hline 6. & Pringsewu & - & - & - & - \\
\hline 7. & Tanggamus & 7 & 3 & 2 & 1 \\
\hline 8. & Lampung Utara & 1 & 1 & - & - \\
\hline 9. & Mesuji & - & - & - & - \\
\hline 10. & Pesawaran & 1 & 2 & 2 & - \\
\hline 11. & Lampung Barat & 6 & 1 & 5 & 1 \\
\hline 12. & Lampung Timur & - & - & - & - \\
\hline 13. & Pesisir Barat & 4 & 1 & 1 & 5 \\
\hline 14. & Tulang Bawang & - & - & - & - \\
\hline 15. & Way Kanan & 3 & - & 1 & - \\
\hline & Jumlah & 25 & 14 & 14 & 8 \\
\hline
\end{tabular}

West Lampung Regency is the area most prone to landslides in Lampung Province [6]. West Lampung Regency is located in the west of the island of Sumatra at an altitude of $800-1100$ meters above sea level, [7] which are mostly hills and hills with slopes $>45 \%$ and there is an active Sumatran fault zone [8] with high rainfall reaching $2000 \mathrm{~mm} / \mathrm{year}$. [1] This causes the potential for landslides in West Lampung Regency to be high.

One of the important factors that cause landslides is a heavy rainfall [9]. The intensity of rainfall is relatively high in a long duration, causing an increase in the water content in the soil which can damage the compact and impermeable rock structure. If water is absorbed for a long time, the soil will become saturated quickly and the soil mass will easily move downwards so that landslides can occur [10] [11] [12] [13].

Rainfall which is one of the important influences on the potential for landslides can be predicted. The level of rainfall will always change from day to day, so accurate rainfall information is needed so that people can know the level of potential for landslides. One way that can be done to get rainfall information is to predict rainfall. There are several studies which state that fuzzy logic can be used to produce rainfall predictions as shown in [11 - 13]. Given the importance of rainfall levels on the potential for landslides in West Lampung Regency, in this study, rainfall prediction was carried out using fuzzy logic with input variables in the form of three factors that most influence the process of rain, namely air temperature, humidity, and wind velocity. 
2. Research Methodology

2.1. BMKG (Badan Meteorologi, Klimatologi, dan Geofisika)
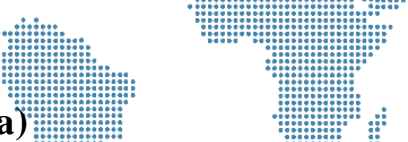

BMKG (Meteorology, Climatology and Geophysics Council) Government Institutions that carry out government duties in the fields of Meteorology, Climatology, Air Quality and Geophysics in accordance with the provisions of applicable laws and regulations. One of BMKG functions is the implementation, guidance and control of observations, and processing of data and information in the fields of meteorology, climatology, and geophysics [14].

\subsection{Meteorology}

Meteorology is the science that studies weather events, while weather is the state of the atmosphere in a limited period of time and space. [12] There are several elements that affect the weather conditions in an area, namely:

a) Temperature.

Air temperature is the degree of hot air that can be measured using a thermometer and is expressed in degrees (usually on the Celsius scale).

b) Pressure.

Air pressure is the pressure exerted by the air per unit area in the flat plane of the earth's surface to the atmospheric limit.

c) Humidity.

Air humidity is the amount of water vapor in the atmosphere.

d) Wind.

Wind is the horizontal movement of air caused by differences in air pressure in one place and another.

e) Rainfall.

Rainfall is the height of rainwater that collects in a flat place, does not evaporate, does not seep, and does not flow. Rainfall of 1 (one) millimeter means that in an area of one square meter on a flat place one millimeter of water can be accommodated or one liter of water can be accommodated. Rain intensity is the amount of rainfall per unit period of time.

\subsection{Fuzzy Logic}

Fuzzy is an aspect of uncertainty that has a mathematical form to see the level of ambiguity and can be expressed in human language using the "fuzzy logic" approach. In fuzzy there is a degree of membership that has a membership interval between 0 and 1 . In fuzzy logic theory a value can be true or false together, but the magnitude of the presence and error depends on the weight of the membership it has [11]. The process of formulating a mapping from a given input into an output using fuzzy logic is called fuzzy inference [15]. There are three methods that are often used in fuzzy inference, one of which is the Mamdani method. The output obtained using the Mamdani method after going through four stages [12]:

a) Fuzzification

In the first stage, there is a process of converting firm values into membership functions, both input and output variables are divided into one or more fuzzy sets.

b) Application Function Implication

In the Mamdani method, the implication function used is min. Combining all input variables by applying the t-norm, which is a slice operation on the fuzzy set.

c) Composition Rules

After the implication process, it is continued with the process of combining fuzzy rules using the max method or combining all the rules used to do the composition between rules. 
d) Defuzzification
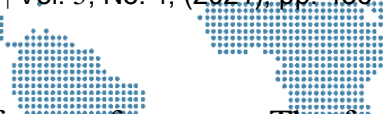

Defuzzification is the process of getting a firm value from a fuzzy set. The fifizzy

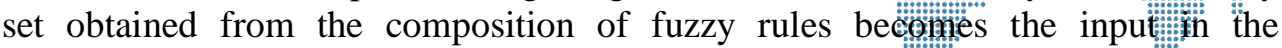
defuzzification, and will be processed into an output in the form of a number in the domain of the fuzzy set.

\subsection{Membership Function}

Membership function has a very important role in presenting the problem. Membership function is a curve that shows the mapping of data input points into the degree of membership with an interval between 0 to 1 . One way to get the membership value is to use a function approach [15]. There are two functions that can be used, namely:

a) Triangular membership function

The triangle membership function uses three parameters $\{a, b, c\}$ which will determine the $\mathrm{x}$-coordinates of the three corners. This curve is a combination of two lines (linear), with the equation:

$$
\mu[x]= \begin{cases}0 & x \leq a \text { atau } x \geq c \\ (x-a) /(b-a) & a \leq x \leq b \\ (c-x) /(c-b) & b \leq x \leq c\end{cases}
$$

The membership function graph is shown in Figure 2. Triangle Membership Function Graph.

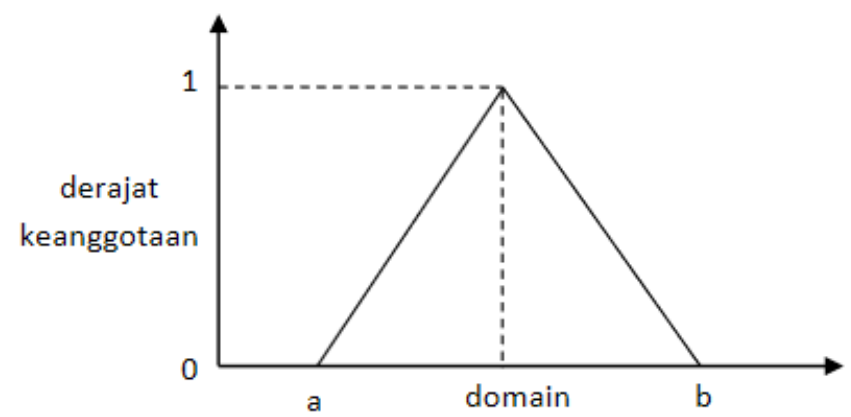

Figure 2. Triangle Membership Function Graph

b) Trapezoid membership function

The trapezoid membership function is basically like a triangle membership function, except that there are several points that have a membership value of 1 . The equation for the trapezoidal curve is:

$$
\mu[x]= \begin{cases}0 & x \leq a \text { atau } x \geq d \\ (x-a) /(b-a) & a \leq x \leq b \\ 1 & b \leq x \leq c \\ (d-x) /(d-c) & c \leq x \leq d\end{cases}
$$

With a membership function graph as shown in Figure 3. Trapezoid Membership Function Graph. 

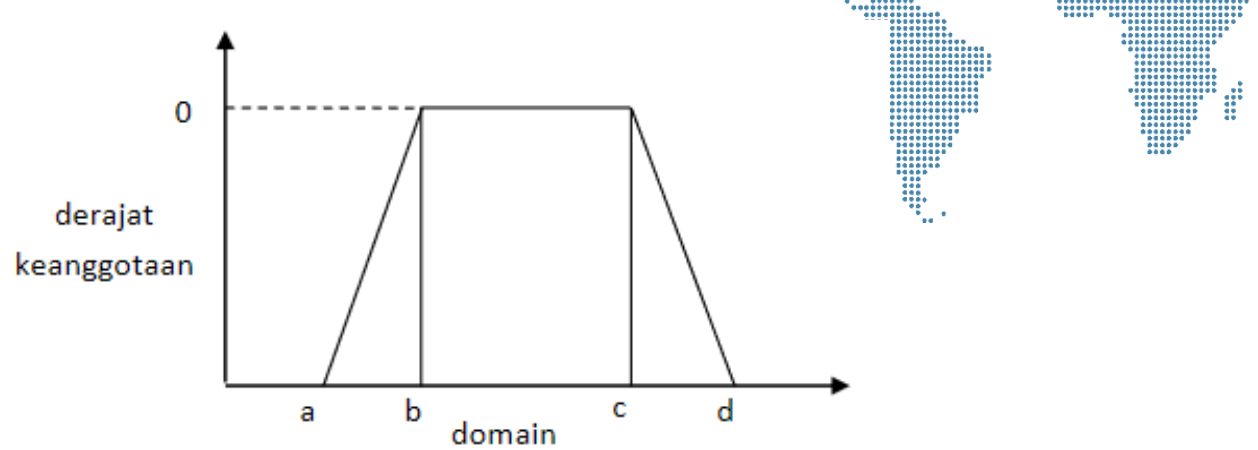

Figure 3. Trapezoid Membership Function Graph

\section{Result and Discussion}

The potential for landslides generally can be known by knowing the prediction of rainfall data, so it is necessary to search for rainfall prediction data which can be used to determine the level of potential landslides. The data used in this research is obtained from BMKG climatology station yearly observation from 2020 to October 2021. Since the data used has lots of missing values, the research used missing values imputation using centroid method approach to fill all the missing values.

1) Input and output variable

Prediction of rainfall is done by using variables that can affect the process of rain.

So, it is necessary to manage input data and output data used in predicting rainfall.

a) Forming input variables and output variables

The input variables are temperature, humidity, and wind velocity, while the output variables are rainfall, using the weekly mean data which will predict the rainfall data for that week.

b) Forming a fuzzy set

A fuzzy set is a group that represents a certain condition in a fuzzy variable.

The linguistic variables used are:

i) Input Variables

Temperature $=\{$ low, medium, high $\}$

Humidity $=\{$ low, medium, high $\}$

Wind Velocity $=\{$ medium, strong, very strong $\}$

ii) Output Variable

Rainfall $=\{$ sunny, light rain, moderate rain, heavy rain, very heavy rain $\}$

c) Forming a universal set of talks for each variable

The universe of conversation as shown at Table 2. Variable Conversation Universe will provide a range of values for each variable that allows rainfall to be formed every day.

Table 2. Variable Conversation Universe

\begin{tabular}{|l|l|l|}
\hline Function & Variable & Conversation Universe \\
\hline \multirow{3}{*}{ Input } & Temperature ${ }^{\circ} \mathrm{C}$ & {$[0,50]$} \\
\cline { 2 - 3 } & Wind Velocity $(\mathrm{m} / \mathrm{s})$ & {$[0,40]$} \\
\cline { 2 - 3 } & Humidity $(\%)$ & {$[0,100]$} \\
\hline Output & Rainfall $(\mathrm{mm})$ & {$[0,150]$} \\
\hline
\end{tabular}

2) Variable Membership Function

The membership function used in this study is a trapezoidal membership function.

a) Membership Function - Temperature 


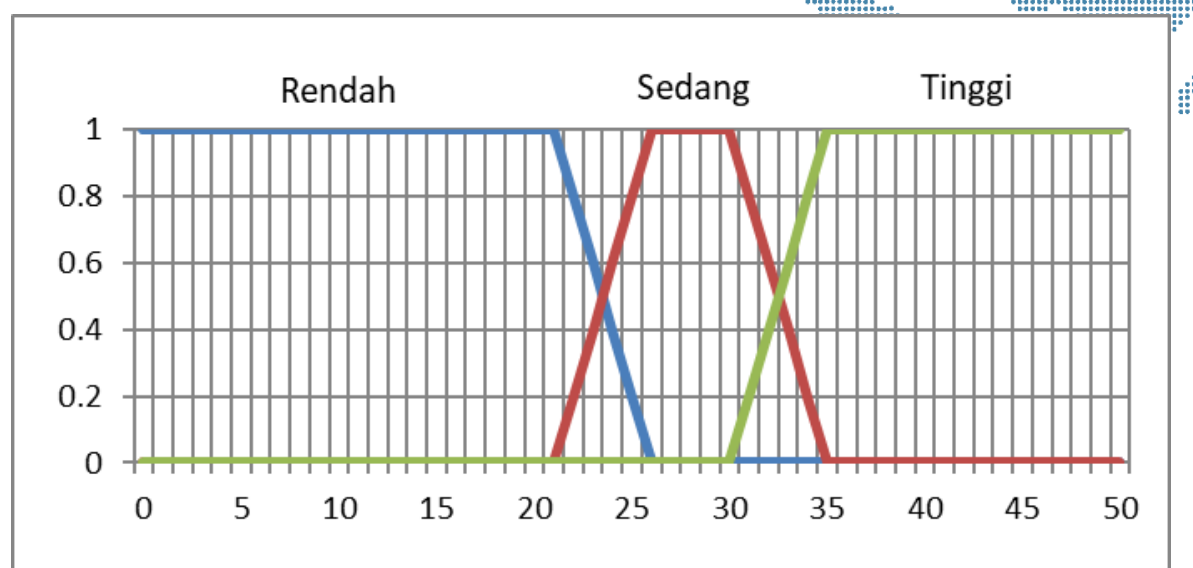

Figure 4. Membership Function Temperature

Figure 4. Membership Function Temperature is the trapezoidal graph for temperature variable, from this graph, we can infer:

$$
\begin{aligned}
& \mu_{\text {rendah }}(x)\left\{\begin{array}{c}
1 ; x<21 \\
\frac{26-x}{5} ; 21<x<26 \\
0 ; x>26
\end{array}\right. \\
& \mu_{\text {sedang }}(x)\left\{\begin{array}{c}
\frac{x-21}{5} ; 26<x<30 \\
\frac{35-x}{5} ; 30<x<35 \\
0 ; x<21, x>35
\end{array}\right. \\
& \mu_{\text {tinggi }}(x)\left\{\begin{array}{c}
1 ; x>35 \\
\frac{x-30}{5} ; 30<x<35 \\
0 ; x<30
\end{array}\right.
\end{aligned}
$$

b) Membership Function - Humidity

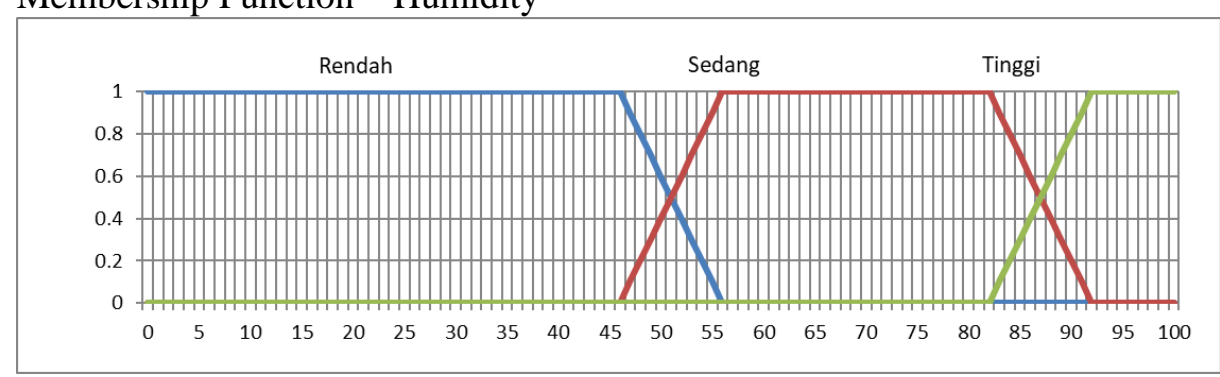

Figure 5. Membership Function Humidity

Figure 5. Membership Function HumidityFigure 4. Membership Function Temperature is the trapezoidal graph for humidity variable, from this graph, we can infer:

$$
\mu_{\text {rendah }}(x)\left\{\begin{array}{c}
1 ; x<46 \\
\frac{56-x}{10} ; 46<x<56 \\
0 ; x>56
\end{array}\right.
$$


$\mu_{\text {sedang }}(x)\left\{\begin{array}{c}1 ; 56<x<82 \\ \frac{x-46}{10} ; 46<x<56 \\ \frac{92-x}{10} ; 82<x<92 \\ 0 ; x<46, x>92\end{array}\right.$

$\mu_{\text {tinggi }}(x)\left\{\begin{array}{c}1 ; x>92 \\ \frac{x-82}{10} ; 82<x<92 \\ 0 ; x<82\end{array}\right.$

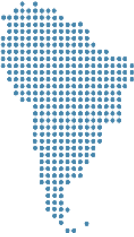

c) Membership Function - Wind Velocity

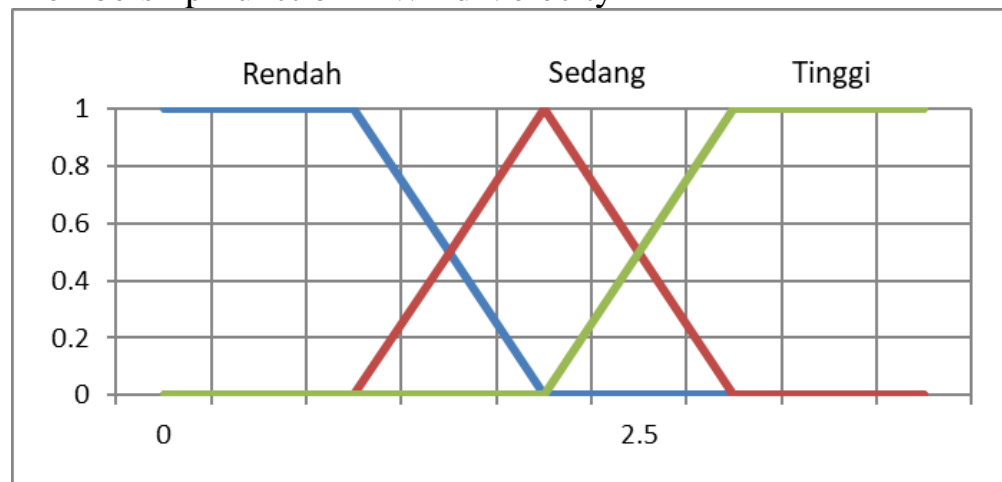

Figure 6. Membership Function Wind Velocity

Figure 6. Membership Function Wind Velocity is the trapezoidal graph for wind velocity variable, from this graph, we can infer:

$$
\begin{aligned}
& \mu_{\text {sedang }}(x)\left\{\begin{array}{c}
1 ; x \leq 1 \\
2-x ; 1<x<2 \\
0 ; x>2
\end{array}\right. \\
& \mu_{\text {kencang }}(x)\left\{\begin{array}{c}
1 ; x=2 \\
x-1 ; 1<x<2 \\
3-x ; 2<x<3 \\
0 ; x<1, x>3
\end{array}\right. \\
& \mu_{\text {sangat kencang }}(x)\left\{\begin{array}{r}
1 ; x \geq 3 \\
x-2 ; 2<x<3 \\
0 ; x<2
\end{array}\right.
\end{aligned}
$$

d) Membership Function - Rainfall

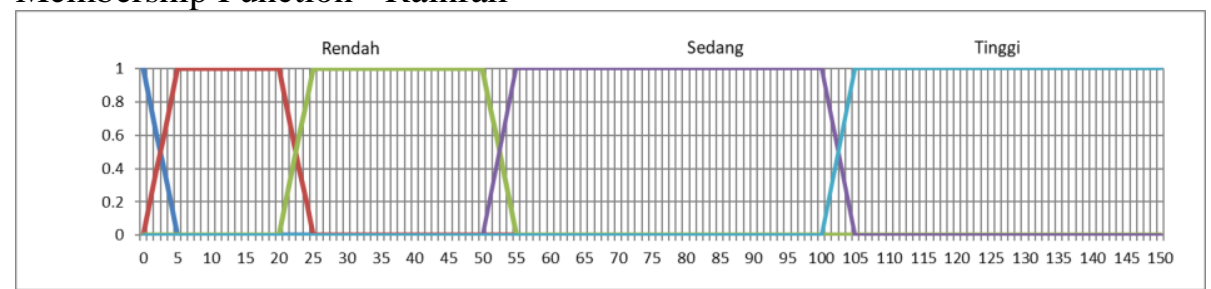

Figure 7. Membership Function Rainfall

Figure 7. Membership Function RainfallFigure 5. Membership Function HumidityFigure 4. Membership Function Temperature is the trapezoidal graph for rainfall variable, from this graph, we can infer: 


$$
\begin{aligned}
& \mu_{\text {cerah }}(x)\left\{\begin{array}{c}
1 ; x=0 \\
\frac{5-x}{5} ; 0<x<5 \\
0 ; x>5
\end{array}\right. \\
& \mu_{\text {ringan }}(x)\left\{\begin{array}{c}
1 ; 5<x<20 \\
\frac{x}{5} ; 0<x<5 \\
\frac{25-x}{5} ; 20<x<25 \\
0 ; x>25
\end{array}\right. \\
& \mu_{\text {sedang }}(x)\left\{\begin{array}{c}
\frac{x-20}{5} ; 20<x<25 \\
\frac{55-x}{5} ; 50<x<55 \\
0 ; x<20, x>25
\end{array}\right. \\
& \mu_{\text {lebat }}(x)\left\{\begin{array}{c}
1 ; 55<x<100 \\
\frac{x-50}{5} ; 50<x<55 \\
\frac{105-x}{5} ; 100<x<105 \\
0 ; x<50, x>105 \\
1 ; x>105
\end{array}\right. \\
& \mu_{\text {tinggi }}(x)\left\{\begin{array}{c}
\frac{x-100}{5} ; 100<x<105 \\
0 ; x<100
\end{array}\right.
\end{aligned}
$$

3) Determination of rules

The rule will be used as a reference of condition by a certain input variable, it will

\begin{tabular}{|c|c|c|c|c|}
\hline No & Kecepatan Angin & Suhu & Kelembaban & Curah Hujan \\
\hline 1 & \multirow[t]{9}{*}{ Sedang } & \multirow[t]{3}{*}{ Rendah } & Tinggi & Hujan Sedang \\
\hline 2 & & & Sedang & Hujan Ringan \\
\hline 3 & & & Rendah & Cerah \\
\hline 4 & & \multirow[t]{3}{*}{ Sedang } & Tinggi & Cerah \\
\hline 5 & & & Sedang & Cerah \\
\hline 6 & & & Rendah & Cerah \\
\hline 7 & & \multirow[t]{3}{*}{ Tinggi } & Tinggi & Cerah \\
\hline 8 & & & Sedang & Cerah \\
\hline 9 & & & Rendah & Cerah \\
\hline 10 & \multirow[t]{9}{*}{ Kencang } & \multirow[t]{3}{*}{ Rendah } & Tinggi & Hujan Lebat \\
\hline 11 & & & Sedang & Hujan Sedang \\
\hline 12 & & & Rendah & Hujan Ringan \\
\hline 13 & & \multirow[t]{3}{*}{ Sedang } & Tinggi & Hujan Ringan \\
\hline 14 & & & Sedang & Cerah \\
\hline 15 & & & Rendah & Cerah \\
\hline 16 & & \multirow{3}{*}{ Tinggi } & Tinggi & Cerah \\
\hline 17 & & & Sedang & Cerah \\
\hline 18 & & & Rendah & Cerah \\
\hline 19 & \multirow[t]{6}{*}{ Sangat Kencang } & \multirow[t]{3}{*}{ Rendah } & Tinggi & $\begin{array}{ll}\text { Hujan } & \text { Sangat } \\
\text { Lebat }\end{array}$ \\
\hline 20 & & & Sedang & Hujan Lebat \\
\hline 21 & & & Rendah & Hujan Sedang \\
\hline 22 & & \multirow[t]{3}{*}{ Sedang } & Tinggi & Hujan Ringan \\
\hline 23 & & & Sedang & Hujan Ringan \\
\hline 24 & & & Rendah & Hujan Ringan \\
\hline
\end{tabular}
produce an output variable with a certain value. Making rules is based on expertise and observation of data in the form of natural habits which shown at Table 3. Data Observation.

Table 3. Data Observation 


\begin{tabular}{|c|c|c|c|c|c|}
\hline No & Kecepatan Angin & Suhu & Kelembaban & : & a \\
\hline 25 & & \multirow[t]{3}{*}{ Tinggi } & Tinggi & Gerah & \\
\hline 26 & & & Sedang & 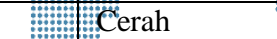 & 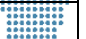 \\
\hline 27 & & & Rendah & : Cerah & 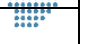 \\
\hline
\end{tabular}

4) Implementation

Comparison between prediction and actual data is shown at Table 4. Result of Rainfall Prediction.

Table 4. Result of Rainfall Prediction

\begin{tabular}{|l|r|r|r|r|r|}
\hline Tanggal & Suhu (C) & Kelembapan (\%) & Curah Hujan $(\mathrm{mm})$ & Kecepatan angin $(\mathrm{m} / \mathrm{s})$ & Prediksi curah hujan \\
\hline $09-08$ sd 15-08 & 27.0 & 86.4 & 7.5 & 1.1 & 12.5 hujan ringan \\
\hline $16-08$ sd 22-08 & 26.8 & 87.3 & 8.2 & 0.7 & 12.6 hujan ringan \\
\hline $23-08$ sd 29-08 & 27.5 & 82.3 & 6.3 & 1.1 & 12.5 hujan ringan \\
\hline $30-08$ sd 05-09 & 27.2 & 87.1 & 6.3 & 0.4 & 12.6 hujan ringan \\
\hline $06-09$ sd 12-09 & 26.7 & 87.1 & 12.6 & 0.7 & 12.6 hujan ringan \\
\hline $13-09$ sd 19-09 & 27.0 & 86.9 & 11.6 & 1.0 & 12.6 hujan ringan \\
\hline $20-09$ sd 26-09 & 27.2 & 88.3 & 13.4 & 0.7 & 12.5 hujan ringan \\
\hline $27-09$ sd 03-10 & 27.6 & 86.6 & 7.4 & 0.3 & 12.6 hujan ringan \\
\hline $04-10$ sd 10-10 & 28.3 & 80.7 & 4.2 & 1.3 & 12.5 hujan ringan \\
\hline $11-10$ sd 17-10 & 28.4 & 83.0 & 3.5 & 0.9 & 12.5 hujan ringan \\
\hline $18-10$ sd 24-10 & 27.4 & 86.6 & 9.6 & 0.9 & 12.6 hujan ringan \\
\hline $25-10$ sd 31-10 & 27.8 & 85.9 & 4.1 & 0.9 & 12.5 hujan ringan \\
\hline
\end{tabular}

'Curah Hujan' column is the rainfall weekly average actual data obtained from BMKG with revised missing values, and the 'Prediksi curah hujan' is the rainfall prediction which resulted in a 'hujan ringan' or light rain. Light rain means that there is a slight potential of landslides to occur.

\section{Conclusion}

Rainfall prediction using fuzzy logic mamdani resulted in a 'light rain' for most of the data given. This prediction will show that there is a slight potential of landslides to occur, which is the result of most of the data. The data obtained from BMKG has lots of missing values which might affect the prediction resulting with most of the prediction is 'light rain', and this also means that fuzzy logic mamdani might not suitable to be used when the data given has lots of missing values.

\section{References}

[1] P. Iqbal, D. Muslim, Z. Zakaria and I. Sophian, "Desain Penahan Longsor di Kabupaten Lampung Barat berbasis Kearifan Lokal (Landslide Mitigation Design based on Local Wisdom)," Badan Penelitian dan Pengembangan Daerah Lampung Barat, Liwa, 2019.

[2] H. S. Naryanto, "Analisis Kejadian Bencana Tanah Longsor di Dusun Jemblung, Desa Sampang, Kecamatan Karangkobar, Kabupaten Banjarnegara, Provinsi Jawa Tengah," Jurnal Alami, vol. 1, no. 1, pp. 1-10, 2017.

[3] Sobirin, F. Sitanala and M. Ramadhan, "Analisis Potensi dan Bahaya Bencana Longsor Menggunakan Modifikasi Metode Indeks Storie di Kabupaten Kebumen Jawa Tengah," Industrial Research Workshop and National Seminar Politeknik Negeri Bandung, pp. 59-64, 26-27 Juli 2017.

[4] B. N. P. Bencana, Risiko Bencana Indonesia, Badan Nasional Penanggulangan Bencana.

[5] P. P. Lampung, Rencana Pembangunan Jangka Menengah Daerah Provinsi Lampung Tahun 2019 - 2024, 2019.

[6] P. K. L. Barat, Dokumen Kajian Risiko Bencana Kabupaten Lampung Barat Provinsi Lampung, Badan Nasional Penanggulangan Bencana. 


\section{Cisinta}

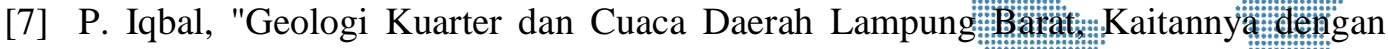

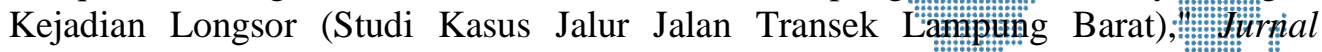
Geologi dan Sumberdaya Mineral, vol. 19, no. 3, pp. 163-169:2018.

[8] S. Prawiradisastra, "Identifikasi Daerah Rawan Bencana Tatha Longsor di Provinsi Lampung," Jurnal Sains dan Teknologi Indonesia, vol. 15, no."1, pp. 52-59, 2013.

[9] L. Kurniawan , "Kajian Penilaian Bahaya Tanah Longsor Provinsi Sumatera Utara," Jurnal Sains dan Teknologi Indones, vol. 10, no. 2, pp. 90-98, 2008.

[10] N. M. D. Pradnyasari, W. and T. Kusmawati, "Pemetaan Potensi dan Kerawanan Longsor Lahan di Desa Belandingan, Desa Songan A dan Desa Songan B Kecamatan Kintamani, Kabupaten Bangli," Jurnal Agroekoteknologi Tropika, vol. 8, no. 2, pp. 231-241, 2019.

[11] D. R. Navianti, I. G. N. R. Usadha and F. A. Widjajati, "Penerapan Fuzzy Inference System pada Prediksi Curah Hujan di Surabaya Utara," JURNAL SAINS DAN SENI ITS, vol. 1, no. 1, pp. A23-A28, 2012.

[12] Z. Julisman and E. , "Prediksi Tingkat Curah Hujan di Kota Pekanbaru menggunakan Logika Fuzzy Mamdani," Jurnal SATIN - Sains dan Teknologi Informasi, vol. 3, no. 1, pp. 65-72, 2014.

[13] U. Mahanani, A. E. Fahrudin and Nurlina, "Penerapan Logika Fuzzy untuk Memprediksi Cuaca Harian di Banjarbaru," Jurnal Fisika FLUX, vol. 12, no. 2, pp. 13-19, 2015.

[14] K. d. G. Badan Meteorologi, "Badan Meteorologi, Klimatologi, dan Geofisika," Badan Meteorologi, Klimatologi, dan Geofisika, [Online]. Available: https://www.bmkg.go.id/profil/?p=tugas-fungsi. [Accessed 17 September 2021].

[15] H. Harys, I. Suprayogi and Rinaldi, "APLIKASI LOGIKA FUZZY UNTUK PREDIKSI KEJADIAN HUJAN (Studi Kasus: Sub DAS Siak Hulu)," Jurnal Online Mahasiswa Fakultas Teknik, vol. 1, no. 1, 2014. 